\title{
Scanning Electron Microscopy of Endophytic Actinomycete Isolate against Fusarium oxysporum for Various Growth Parameters on Musk Melon
}

\author{
Priyanka Kamboj ${ }^{1 *}$, Madhurama Gangwar ${ }^{1}$ and Narinder Singh ${ }^{2}$ \\ ${ }^{1}$ Department of Microbiology, ${ }^{2}$ Department of Plant Pathology, \\ Punjab Agricultural University, Ludhiana-141004, Punjab, India \\ *Corresponding author
}

\section{A B S T R A C T}

\section{Keywords}

Endophytic

actinomycetes,

Fusarium oxysporum,

SEM, Emblica

officinalis.

Article Info

Accepted:

07 September 2017

Available Online:

10 November 2017
The development of phytobeneficial actinomycetes strains that suit local environmen may help to enhance competitiveness with in situ microorganisms and effectiveness in suppressing phytopathogenic fungi. Scanning electron microscopy of AR3 with $F$. oxysporum revealed immense distortion of fungal cell wall. The endophytic actinomycete isolated from the Emblica officinalis assessed for growth-promoting parameters on musk melon variety Punjab sunehri. In the pot house, musk melon seed germination, root length, shoot length, root fresh and dry weight, shoot fresh and dry weight were significantly enhanced with the inoculation of AR3 potential isolate and also there is significant inhibition of disease appearance.

\section{Introduction}

Biological control of plant diseases is slow rather gives few quick profits, but can be long lasting, inexpensive and harmless to life. The control of plant diseases is an urgent need for sustainable agriculture (Ara et al., 2012). The application of agrochemicals is still an important method in agricultural practices, but has some detrimental effects on non-target organisms. Several efforts have been made to find less hazardous options for controlling these plant pathogens among which the biological control using the microorganisms has been demonstrated to be a feasible alternative (Zucchi et al., 2008). Among the biocontrol agents, endophytic microorganisms especially actinomycetes from medicinal plants have raised special attention, mainly due to their crucial role on host-plant development (Firakova et al., 2007). Actinomycetes are also found inside plants as endophytes.

They are Gram-positive widely distributed group of microorganisms in nature. They are also well known as saprophytic soil inhabitants (Takizawa et al., 1993). They are characterized by having a high $\mathrm{G}+\mathrm{C}$ content (>55\%) in their DNA (Bizuye et al., 2013) Since these symbionts are systemically distributed in the plant via metabolic 
translocation colonizing the same niche of the phytopathogens so they are interesting candidates for the biological control (Rai et al., 2007). Endophytic actinomycetes produced the natural antibiotics being less polluting and less stressful on indigenous microbes. Fungal plant diseases are considered to be serious problems with a wide host range and globally distribution.

Fusarium oxysporum is responsible for some plant diseases such as wilt and root rot in various crops. Actinomycetes have the ability to colonize plant root surfaces by providing protection from plant pathogens. These bio agents compete for space by synthesizing extracellular enzymes that attack the phytopathogenic fungal cell wall. Actinomycetes can promote the growth of many field crops by producing plant growthpromoting substances like indole-3-acetic acid (IAA) to help the growth of roots and by fixing nitrogen from the atmosphere. These are also the potential sources of novel natural products for exploitation in medicine, agriculture and industry (Kumar et al., 2011). In addition, endophytes are known to compete with phytopathogens for nutrients (ElTarabily and Sivasithamparam, 2006). They produce siderophore to bind $\mathrm{Fe}^{3+}$ from the environment and help to improve nutrient uptake.

All the properties exhibited by actinomycetes, especially, Streptomyces not only give us a better understanding of their environmental and ecological benefits, but also in their impact as an attractive alternative for use in agriculture (Errakhi et al., 2007; Joo, 2005; Xiao et al., 2002).

The present research was undertaken to study the antagonistic effect of potential endophytic actinomycete isolate on the growth of Fusarium oxysporum on musk melon plants under greenhouse conditions.

\section{Materials and Methods}

\section{Fungal strain and culture conditions}

The fungal pathogen $F$. oxysporum was isolated and obtained from the Department of Plant Pathology, PAU, Ludhiana. The procured fungi was grown on potato dextrose agar (PDA) plates and incubated at $28^{\circ} \mathrm{C}$ for 4 to 6 days. Stock culture of test fungi was maintained on PDA slants and stored at $4^{\circ} \mathrm{C}$.

\section{Endophytic actinomycete culture}

Actinomycete isolate used for carrying out present study was procured from Department of Microbiology, PAU, Ludhiana. The stock culture was maintained on Starch Casein Agar slants by regular sub-culturing and stored at $4^{\circ} \mathrm{C}$.

Scanning electron microscopic (SEM) studies of potential actinomycete isolate on fungal cell wall

Scanning electron microscopy (SEM) of actinomycete isolate AR3 treated with Fusarium oxysporum culture was performed using chemical fixation and liquid osmium fixation technique (Bozzola and Russell, 1996). Samples were fixed in $2.5 \%$ gluteraldehyde solution (fixative) at $4^{\circ} \mathrm{C}$ for 24 hours. After fixation the gluteraldehyde was drained and three washings with $0.1 \mathrm{M}$ sodium cacodylate buffer ( $\mathrm{pH}$ 7.2) were performed after the interval of 15 minutes at $4^{\circ} \mathrm{C}$. Wash buffer was drained and $1 \%$ Osmium tetraoxide $\left(\mathrm{OsO}_{4}\right)$ was added for 1-2 hours at $4^{\circ} \mathrm{C}$. As $\mathrm{OsO}_{4}$ is slow penetrating solution the samples were placed in liquid osmium tetraoxide for 2 to 3 hours. Later $\mathrm{OsO}_{4}$ solution was drained off followed by three washings with the rinsing buffer solution (0.1 M sodium cacodylate buffer) for 15 minutes at $4^{\circ} \mathrm{C}$ each. After fixation step dehydration was done by incubating the 
samples with the ethanol solution of different concentrations starting with $30 \%, 50 \%$ and $70 \%$ ethanol solution each for 15 minutes at $4^{\circ} \mathrm{C}$ (sample can be stored in $70 \%$ ethanol at $4^{\circ} \mathrm{C}$ for three to four days). Then further samples were incubated in $80 \%, 90 \%$ and 95\% ethanol solution each for 15 minutes. Samples were then incubated three times in the $100 \%$ ethanol solution each for 20 minutes at room temperature. The solution was drained off at last and sample was placed in the vacuum dessicator overnight, stubbed and sputter coated with gold in E-1010 Ion sputter coater machine to be viewed under secondary electron imaging mode in Hitachi S-3400N Scanning electron microscope.

\section{Effectiveness evaluation of endophytic actinomycete isolate AR3 as potential antagonist against Fusarium oxysporum in pot house}

\section{Inoculum preparation of potential antagonist}

The potential isolates was grown in broth medium for 5 days. Healthy seeds of musk melon variety Punjab sunehri were surface sterilized with $0.1 \% \mathrm{HgCl}_{2}$ for 3 min followed by treatment with $95 \%$ ethanol for 5 minutes and then successive washing with sterilized distilled water. The surface sterilized seeds were immersed overnight in the antagonist suspension containing $10^{8} \mathrm{cfu} / \mathrm{ml}$.

\section{Fungal inoculum preparation}

Inoculum of phytopathogenic fungi Fusarium oxysporum was prepared by soaking wheat seeds overnight in water. Sand and soaked wheat seeds were mixed and transferred to $250 \mathrm{ml}$ Erlenmeyer flasks and autoclaved at $121^{\circ} \mathrm{C}$. Fusarium oxysporum was grown on potato dextrose agar and discs of fungi were transferred to $250 \mathrm{ml}$ Erlenmeyer flasks containing autoclaved wheat and sand. The flasks were incubated at $25^{\circ} \mathrm{C}$ for 7 days. The rate of inoculum applied to the potting mixture was $10 \mathrm{gm}$ of fungi in $9 \mathrm{~kg}$ of soil per pot. Inoculum of fungus was added in sterile soil before sowing the seeds.

\section{Soil infestation}

Soil was taken from field and sterilized by autoclaving at $121^{0} \mathrm{C}$ for $1 \mathrm{hr}$ for 3 consecutive days. Musk melon seeds variety Punjab sunehri were grown in pots, using completely randomized block design (CRD) with and 4 treatments and 3 replications each. Five seeds were sown per pot containing $9 \mathrm{~kg}$ of sterile soil. The treatments comprised were: (A) Control without antagonist and Fusarium oxysporum (Negative control), (B) Fusarium oxysporum inoculation (Positive control), (C) Endophytic actinomycete isolate AR3 alone (D) Endophytic actinomycete isolate AR3 + Fusarium oxysporum.

\section{Observations to be recorded}

\section{Percentage of seed germination}

Total numbers of seeds germinated were counted and then percent germination was calculated as follows:

Total number of seed germinated

Germination $(\%)=$ $\times 100$

Total number of seeds sown

\section{Plant growth parameters}

Plants were removed with root system intact and then measured for fresh weight. Shoots were randomly selected and uprooted plants from each pot were sun dried and then oven dried at $60^{\circ} \mathrm{C}$ for 1 day. Root and shoot length was measured with simple measuring scales separately. The plants were counted with wilting symptoms and then wilt incidence and inhibition of disease was calculated with 
comparison of control with other treatments as follows:

Total number of wilted plants Incidence of disease $(\%)=$

Total number of plants

Inhibition of Disease development $(\%)=$

Wilt incidence

$\times 100$

Wilt incidence in control

\section{Results and Discussion}

\section{Scanning electron microscopy (SEM)}

Scanning electron micrographs showed the degradation of Fusarium oxysporum cell wall due to secretion of diffusible compounds by AR3 as compared to control (Fig. 1). Fungal colony inoculated with AR3 showed hyphae disruption on the PDA plates due to osmosis or due to intake of water into the cells. The control plate of Fusarium oxysporum showed sectored regular vegetative cells with smooth surface. Spores were deformed partially with reduced size and cytoplasmic structures were flushed out of the cells. Our results are in conformity with several studies carried out by other investigators. Tang-um and Niamsup, (2012a) reported the breakage of the cell wall of Fusarium oxysporum f.sp. lycopersici mycelia growing towards Streptomyces sp. P4. The effect was investigated and compared with the control. He et al., (2009) reported that endophytic bacteria obtained from Epimedium brevicornu degraded the hypha of Sclerotinia sclerotiorum and the cytoplasm was extravagated outside from the fungal wall. The $C$. sublineolum hyphae surfacetreated with A8 culture filtrate contained many holes, possibly corresponding to lysis zones. However, the hyphal surfaces of both C. sublineolum and Pythium sp. treated with A8 culture filtrate exhibited a slightly roughened surface, indicating little or no effect of hydrolytic enzymes on these structures (Quecine et al., 2008).

Table.1 Effect of actinomycete isolate AR3 isolated from Emblica officinalis on various growth parameters

\begin{tabular}{|c|c|c|c|c|c|c|c|c|c|}
\hline Treatments & $\begin{array}{c}\text { Germination } \\
\% \text { (gm) }\end{array}$ & $\begin{array}{c}\text { Root } \\
\text { fresh } \\
\text { weight } \\
\text { (gm) }\end{array}$ & $\begin{array}{c}\text { Shoot } \\
\text { fresh } \\
\text { weight } \\
\text { (gm) }\end{array}$ & $\begin{array}{c}\text { Root } \\
\text { dry } \\
\text { weight } \\
\text { (gm) }\end{array}$ & $\begin{array}{c}\text { Shoot } \\
\text { dry } \\
\text { weight } \\
\text { (gm) }\end{array}$ & $\begin{array}{l}\text { Root } \\
\text { length } \\
(\mathrm{cm})\end{array}$ & $\begin{array}{l}\text { Shoot } \\
\text { length } \\
\text { (cm) }\end{array}$ & $\begin{array}{c}\text { Wilt } \\
\text { incidence } \\
(\%)\end{array}$ & $\begin{array}{c}\text { Inhibition } \\
\text { of disease } \\
(\%)\end{array}$ \\
\hline $\begin{array}{l}\text { Negative } \\
\text { control }\end{array}$ & 73.33 & 0.352 & 6.13 & 0.126 & 1.56 & 7.0 & 35.75 & - & \\
\hline Positive control & 66.66 & 0.299 & 5.00 & 0.111 & 1.26 & 6.0 & 43.11 & 70 & - \\
\hline AR3 & 93.33 & 0.587 & 10.09 & 0.154 & 2.46 & 11.5 & 53.03 & - & - \\
\hline $\begin{array}{l}\text { AR3+ } \\
\text { F.oxysporum }\end{array}$ & 82.00 & 0.375 & 8.40 & 0.130 & 1.38 & 7.16 & 50.27 & 18.18 & 25.97 \\
\hline CD at $5 \%$ & & 0.110 & 1.33 & $\mathrm{NS}$ & 0.652 & NS & 1.29 & & \\
\hline
\end{tabular}


Fig.1 SEM analysis of Fusarium oxysporum control (A),

Fusarium oxysporum co-cultured with AR3 (B)

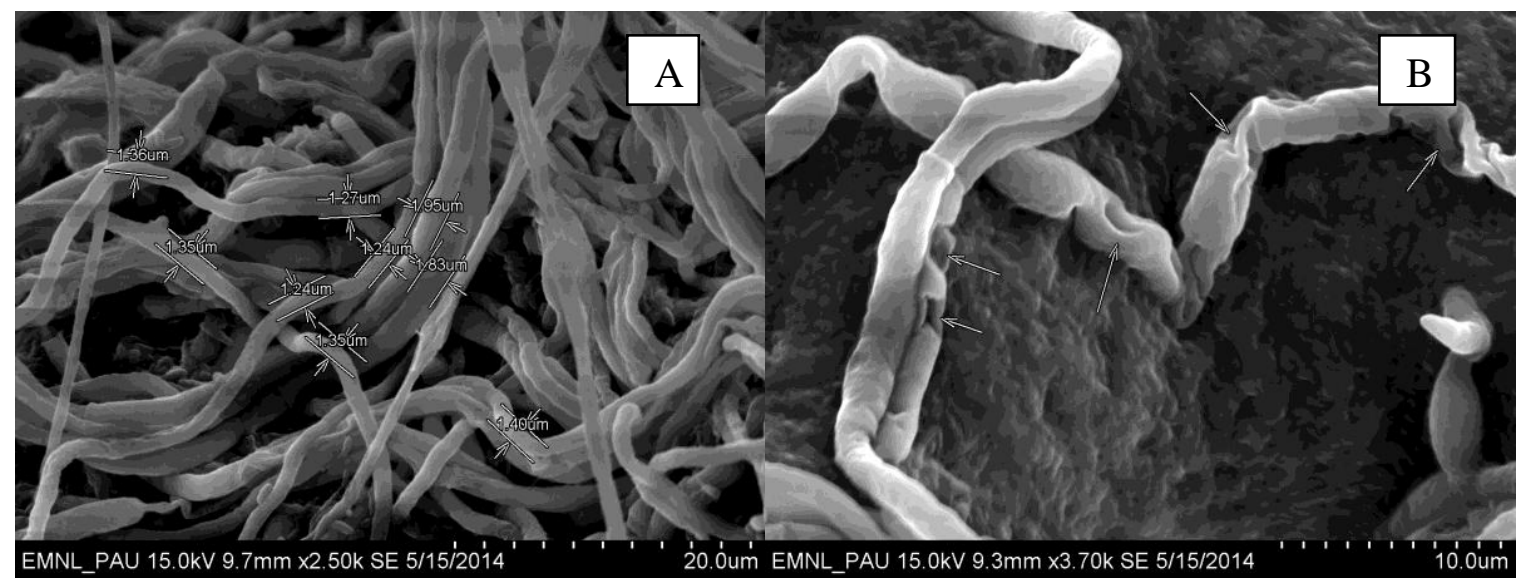

Fig.2 Wilting in different treatments Control (A), AR3 (B), Fusarium oxysporum (C), AR3 + Fusarium oxysporum (D)
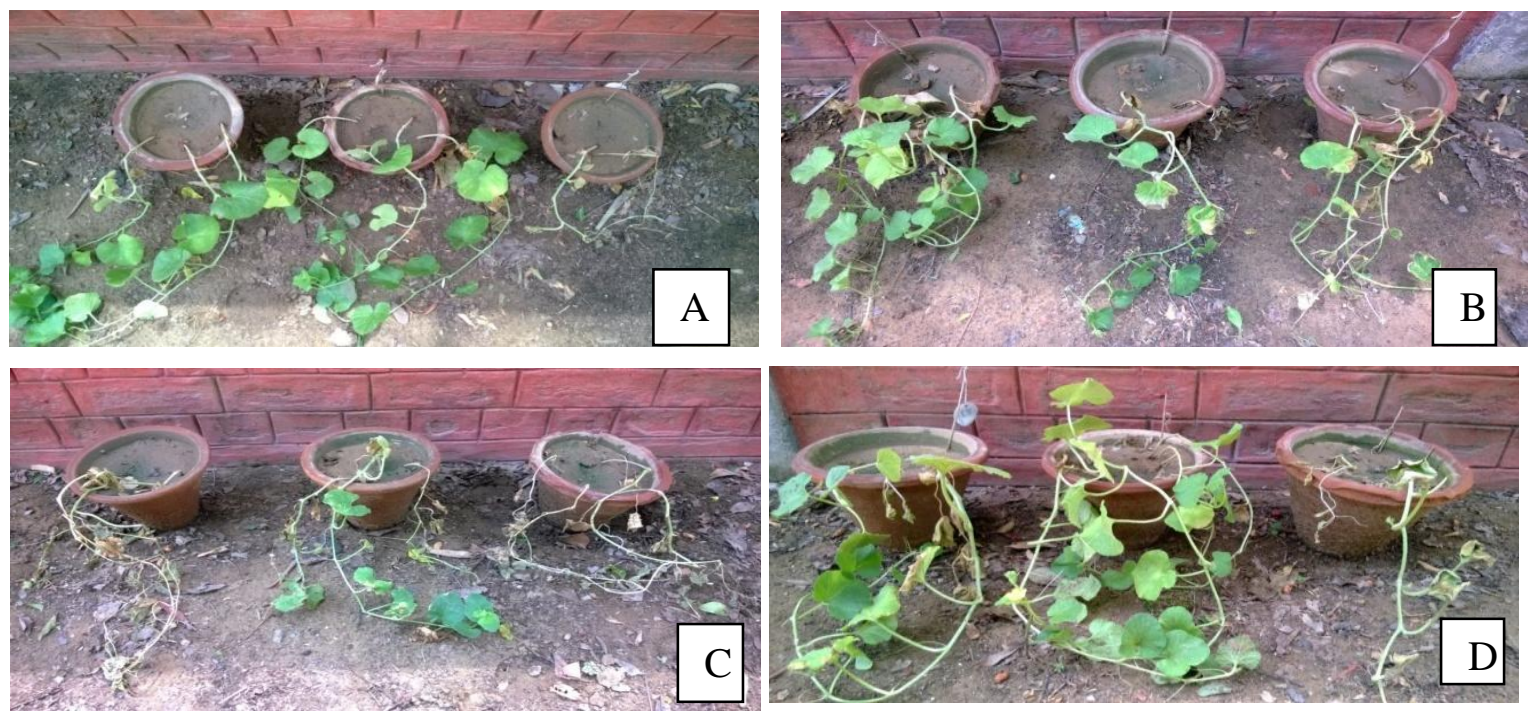

Effects of inoculation of endophytic actinomycete on plant growth parameters of musk melon variety Punjab sunehri

Maximum seed germination was observed by AR3 $(93.33 \%)$ and minimum was recorded in uninoculated control $(73.33 \%)$ followed by treatment with Fusarium oxysporum (66.66\%). Maximum root enhancement was recorded in AR3 (11.5 $\mathrm{cm}^{\text {plant }}{ }^{-1}$ at $\left.60 \mathrm{DAS}\right)$. Root length was measured to be less in treatment with Fusarium oxysporum $(6.0 \mathrm{~cm}$ plant $^{-1}$ at 60 DAS). Shoot length in AR3 + Fusarium oxysporum was recorded maximum (50.27 $\mathrm{cm} \mathrm{plant}^{-1}$ at 60 DAS) as compared to Fusarium oxysporum $\left(43.11 \mathrm{~cm} \mathrm{plant}^{-1}\right.$ at 60 DAS). Root and shoot fresh weight was significantly maximum with AR3 alone. The root dry weight was found more with AR3 (Table 1). The shoot dry weight was observed minimum with Fusarium oxysporum (1.26 gm plant $^{-1}$ ) as compared to AR3 with Fusarium oxysporum (1.38 gm plant $\left.{ }^{-1}\right)$. Wilt incidence was observed in the treatment with Fusarium 
oxysporum (Fig. 2). The inhibition of wilt was found to be effective with AR3 inoculated with Fusarium oxysporum. Gopalakrishnan et al., (2011b) found that Streptomyces sp. isolated from herbal vermi-compost were reported to have the potential for biocontrol of Fusarium wilt caused by Fusarium oxysporum f. sp. ciceri in chickpea and Streptomyces griseoviridis (Mycostop) reduced the percentage of disease caused by Fusarium oxysporum f. sp. radicis cucumerinum. Shirling and Gottlieb (1966) also stated that actinomycetes are an enormous reservoir for bioactive metabolites against phytopathogens.

Based on the results obtained in the present investigation, it revealed that the scanning electron microscopy of antagonist AR3 isolated from Emblica officinalis, a medicinal plant highlights its potential antifungal effect by disrupting the fungal cell wall via hydrolytic enzyme production. Further, it proved to be effective biological control agent by inhibiting the occurrence of disease in musk melon planting system under greenhouse conditions.

\section{References}

Ara, I., Bukhari, N.A., Perveen, K and Bakir, M.A. 2012. Antifungal activity of some actinomycetes isolated from riyadh soil, Saudi Arabia: An evaluation for their ability to control Alternaria caused tomato blight in green house pot trial. Afr. J. Agric. Res., 7: 2042-50.

Bozzola, J.J and Russell, D.L. 1996. Electron Microscopy, Second Edition, pp 202-39.

El-Tarabily, K.A and Sivasithamparam, K. 2006. Non-streptomycete actinomycetes as biocontrol agents of soil-borne fungal plant pathogens and as plant growth promoters. Soil. Biol. Biochem., 38: 1505-20.

Errakhi, R., Bouteau, F., Lebrihi, A and
Barakate, M. 2007. Evidences of biological control capacities of Streptomyces spp. against Sclerotium rolfsii responsible for damping-off disease in sugar beet (Beta vulgaris L.). World. J. Microbiol. Biotechnol., 23: 1503-9.

Firakova, S., Sturdikova, M and Muckova, M. 2007. Bioactive secondary metabolites produced by microorganisms associated with plants. Biologia., 62: 251-57.

Gopalakrishnan, S., Pande, S., Sharma, M., Humayun, P., Kiran, B.K, Sandeep, D., Vidya, M. S., Deepthi, K and Rupela, O. 2011. Evaluation of actinomycete isolates obtained from 46 herbal vermicompost for biological control of Fusarium wilt of chickpea. Crop. Prot., 30:1070-78.

He, R.L., Wang, G.P., Liu, X.H., Zhang, C.L and Lin, F.C. 2009. Antagonistic bioactivity of an endophytic bacterium isolated from Epimedium brevicornu Maxim. Afr. J. Biotechnol., 8: 191-95.

Joo, G.J. 2005. Production of an anti-fungal substance for biological control of Phytophthora capsici causing phytophthora blight in red-peppers by Streptomyces halstedii. Biotechnol. Lett., 27: 201-05.

Kumar, U., Singh, A and SivaKumar, T. 2011. Isolation and screening of endophytic actinomycetes from different parts of Emblica officinalis. Ann. Biol. Res., 2: 423-34

Quecine, M.C., Araujo, W.L., Marcon. J., Gai, C.S., Azevedo, J.L and Kleiner, A.A.P. 2008 Chitinolytic activity of endophytic Streptomyces and potential for biocontrol. Lett. Appl. Microbiol. 47: 486-91

Rai, R., Dash, P. K., Prasanna, B. M and Singh, A. 2007. Endophytic bacterial flora in the stem tissue of a tropical maize (Zea mays L.) genotype: isolation, identification and 
enumeration. World. J. Microbiol. Biotechnol. 23: 853-58.

Shirling, E.B and Gottlieb, D. 1966. Methods for characterization of Streptomyces species. Int. J. Syst. Bacteriol., 16: 313340.

Tang-um, J and Niamsup, H. 2012a. Chitinase production and antifungal potential of endophytic Streptomyces strain P4. Maejo. Int. J. Sci. Technol., 6: 95-104.
Biological control of Phytophthora root rots on alfalfa and soybean with Streptomyces. Biol. Control., 23: 28595.

Zucchi, T. D., Moraes, L.A and Melo, I.S 2008. Streptomyces sp. ASBV-1 reduces aflatoxin accumulation by Aspergillus parasiticus in peanut grains. J. Appl. Microbiol. 105: 2153-60.

Xiao, K., Kinkel, L.L., Samac, D.A 2002.

\section{How to cite this article:}

Priyanka Kamboj, Madhurama Gangwar and Narinder Singh. 2017. Scanning Electron Microscopy of Endophytic Actinomycete Isolate against Fusarium oxysporum for Various Growth Parameters on Musk Melon. Int.J.Curr.Microbiol.App.Sci. 6(11): 458-464. doi: https://doi.org/10.20546/ijcmas.2017.611.054 